\title{
PENGARUH MODEL PEMBELAJARAN BERBASIS PROYEK (PROJECT BASED LEARNING) TERHADAP MINAT BELAJAR DAN KETERAMPILAN PROSES SAINS SISWA PADA PEMBELAJARAN FISIKA DI SMAN BALUNG
}

\author{
${ }^{1)}$ Muhammad Khoirur Roziqin, ${ }^{1)}$ Albertus Djoko Lesmono, ${ }^{1)}$ Rayendra Wahyu Bachtiar \\ Program Studi Pendidikan Fisika FKIP Universitas Jember \\ Email: ziqinzehg@gmail.com
}

\begin{abstract}
Interest in learning was one of the factors that affected student learning outcomes. Physical learning in the form of products, processes and scientific attitude required skills that process on the scientific performance called the science process skills. Project-based learning presents learning in the form of scientific processes and attitudes that could foster students' learning motivation. This research was an experimental research. The purpose of this research was to examine the effect of project based learning model on learning interest and students' science process skill in physics learning at SMAN Balung. Data of student's interest in physics learning was obtained from questionnaire and data of science process skill obtained from post test and there were supporting data in the form of documentation, interview, and observation. The result of the independent sample ttest on the interest of physics learning showed the interest of experimental class physics learning better than the control class. While the results of mann-whitney test on the science process students 'skills showed the students' experimental class science process skills better than the control class. Based on the analysis it could be concluded that the project based learning model had a significant effected on the students' learning interest and science process skills on physics learning at SMAN Balung.
\end{abstract}

Keyword: interest, project based learning model, science process skill

\section{PENDAHULUAN}

Pembelajaran fisika merupakan pembelajaran sains sehingga harus memberikan pembelajaran fisika berupa produk, proses dan sikap ilmiah. Menurut Hila et al. (2015) bahwa dimensi sains sebagai proses berkaitan dengan keterampilan untuk memperoleh atau menemukan konsep dan prinsip. Pembelajaran fisika sebagai proses bisa dilakukan dengan pembelajaran menggunakan metode observasi dan eksperimentasi. Observasi dan eksperimentasi yang dilakukan oleh siswa merupakan aktivitas sains yang membutuhkan keterampilan proses sains.
Keterampilan proses sains meliputi keterampilan fisik dan mental yang berproses pada kerja ilmiah, sehingga dalam pengembangannya membutuhkan pengalaman secara nyata. Menurut Rustman (dalam Budianti dan Safiyyah, 2015), "keterampilan proses sains perlu dikembangkan melalui pengalaman langsung, sebagai pengalaman belajar dan disadari ketika kegiatannya sedang berlangsung". Oleh karena itu, guru dalam pembelajaran fisika hendaknya menciptakan pembelajaran yang dapat melibatkan siswa secara langsung dalam suatu proses sains atau kinerja ilmiah. 
Markawi (2013) menyatakan bahwa Ilmuan menggunakan berbagai keterampilan metode ilmiah, yang disebut keterampilan proses sains yang juga merupakan salah satu pendekatan dalam mempelajari sains. Salah satu faktor yang mempengaruhi prestasi atau hasil belajar siswa adalah minat belajar. Menurut Leung (2015), minat individu peserta didik dalam belajar fisika, mempunyai pengaruh yang positif dalam pembelajaran fisika. Oleh karena itu penggunaan strategi pembelajaran oleh guru seharusnya mampu membangkitkan minat belajar siswa di dalam pembelajaran fisika.

Wati et al. (2017) menyatakan bahwa minat adalah aspek kepribadian yang berkaitan dengan hasil belajar, hal ini dikarenakan minat merupakan suatu kecenderungan untuk memperhatikan dan mengenal sesuatu. Sembiring dan Mukhtar (2013) mengemukakan bahwa minat merupakan suatu kecenderungan untuk bertingkah laku, yang beroreantasi pada objek, kegiatan atau pengalaman tertentu dan kecenderungan tersebut antara individu satu dengan yang lain sama intensitasnya.

Permasalahan yang sering terjadi pada pembelajaran fisika umumnya adalah kurangnya minat belajar siswa pada pembelajaran fisika. Menurut Nurmaliati (2017), bahwa di dalam proses pembelajaran guru tidak bisa memotivasi siswa untuk belajar, proses pembelajaran cenderung monoton, dimana guru hanya menjelaskan materi, memberikan kesempatan untuk bertanya dan menyelesaikan masalah. Penyebab lain berkurangnya minat siswa belajar fisika dikarenakan pembelajaran fisika masih dominan menggunakan pembelajaran teacher centered.

Neizhela dan Mosik (2015) dalam penelitiannya mengemukakan bahwa pelaksanaan pembelajaran fisika masih cenderung menggunakan metode konvensional (ceramah) jadi kurang mengaktifkan siswa dalam proses belajar . Wawancara kepada guru fisika di SMAN Balung dan beberapa SMA lain di Kabupaten Jember, dapat disimpulkan bahwa minat belajar fisika dan keterampilan proses sains siswa dalam pembelajaran masih perlu ditingkatkan. Salah satu yang mempengaruhi hal tersebut adalah penggunaan model pembelajaran yang efektif belum sepenuhnya dilaksanakan.

Minat belajar menunjukan rasa senang, ketertarikan, perhatian, dan kerlibatan seseorang dalam proses belajar. Salah satu yang mempengaruhi minat belajar seseorang adalah motivasi belajar. Hartono (2016) menyatakan bahwa motivasi belajar mencakup: tekun menghadapi tugas dan ulet menghadapi kesulitan, menunjukkan minat terhadap bermacam-macam masalah, Lebih senang bekerja sendiri, Tidak cepat bosan pada tugas-tugas rutin,dapat mempertahankan pendapatnya, senang mencari dan memecahkan masalah soal-soal. Na'imah et al. (2015) didalam penelitiannya, menyatakan bahwa model pembelajaran berbasis proyek berbantuan e-learning memberikan kesempatan kepada siswa untuk berpartisipasi secara aktif terhadap pembelajaran yanng melibatkan siswa secara dalam suatu pembelajaran sehingga mampu memberikan kesan yang menyenangkan dan membangkitkan motivasi serta minat belajar siswa.

Berdasarkan beberapa penelitian yang relevan: Kholifudin (2013) menunjukan bahwa pembelajaran berbasis proyek dapat meningkatkan kerja ilmiah dan sikap ilmiah siswa SMA Negeri 2 Kebumen. Hardianti et al. (2016) menunjukan bahwa hasil belajar siswa dengan menggunakan model pembelajaran berbasis proyek lebih baik dari pada menggunakan model pembelajaran langsung pada kelas $\mathrm{X}$ di SMA Negeri Palu. Setiyatmoko (2015) menunjukan bahwa pembelajaran berbasis proyek dapat meningkatkan prestasi belajar dan kinerja ilmiah siswa di SMA Negeri Semaraputera. Menurut Sastrika et al.(2013), model pembelajaran berbasis 
proyek (Project Based Learning) mendorong siswa melakukan inkuiry seperti mampu membuat rumusan masalah, tujuan, menentukan langkah-langkah pembuatan percobaan sehingga mampu membangun konsep secara mandiri. Model pembelajaran berbasis proyek (Project Based Learning), merupakan model pembelajaran yang secara efektif dapat digunakan untuk mengatasi permasalahan di dalam pembelajaran fisika.

Berdasarkan deskripsi model pembelajaran berbasis proyek (Project Based Learning), peneliti memiliki asumsi bahwa model pembelajaran berbasis proyek (Project Based Learning), mampu meningkatkan minat belajar dan keterampilan proses sains siswa dalam pembelajaran fisika di SMAN Balung. Adapun tujuan penelitian ini antara lain: (1) mengkaji pengaruh model pembelajaran berbasis proyek (Project Based Learning) terhadap minat belajar siswa pada pembelajaran fisika di SMAN Balung; dan (2) mengkaji pengaruh model pembelajaran berbasis proyek (Project Based Learning) terhadap keterampilan proses sains siswa pada pembelajaran fisika di SMAN Balung.

\section{METODE}

Jenis penelitian ini adalah eksperimen dengan menggunakan postestonly control design. Penentuan tempat penelitian ini menggunakan metode purposive sampling area. Populasi yang digunakan dalam penelitian ini adalah siswa kelas X MIA di SMAN Balung. Kelas yang menjadi populasi penelitian ini terdiri dari kelas $\mathrm{X}$ MIA 1, X MIA 2, X MIA 3, X MIA 4, X MIA 5 dan X MIA 6. Teknik yang digunakan untuk menentukan sampel adalah teknik cluster random sampling yaitu pengambilan kelompok sampel dari populasi dilakukan secara acak tanpa memandang strata yang ada dalam populasi. Sampel penelitian ini adalah kelas X MIA 2 sebagai eksperimen dan kelas X MIA 3 sebagai kelas kontrol.
Data minat belajar didapatkan dengan menggunakan angket minat belajar sedangkan untuk data keterampilan proses sains didapatkan dari test unjuk kerja siswa. Teknik analisis data yang digunakan dalam penelitian ini menggunakan uji independen sample t-test dengan bantuan SPSS 22 untuk menguji pengaruh model pembelajaran berbasis proyek (project based learning) terhadap minat belajar siswa dan menggunakan uji Mann-Whitney $U$ untuk menguji pengaruh model pembelajaran berbasis proyek (project based learning) terhadap keterampilan proses sains siswa pada pembelajaran fisika di SMAN Balung.

\section{HASIL DAN PEMBAHASAN}

Data minat belajar siswa diperoleh melalui penilaian angket minat belajar yang dilakukan dengan menggunakan lembar penilaian angket belajar setelah kegiatan belajar mengajar pada materi gerak parabola selesai. Rincian data minat belajar siswa secara ringkas dapat dilihat pada Tabel 1 dan Tabel 2.

Tabel 1. Rata-rata nilai minat belajar siswa

\begin{tabular}{cccc}
\hline No & & $\begin{array}{c}\text { Kelas } \\
\text { Eksperimen }\end{array}$ & $\begin{array}{c}\text { Kelas } \\
\text { Kontrol }\end{array}$ \\
\hline 1. & $\begin{array}{c}\text { Jumlah } \\
\text { Siswa }\end{array}$ & 40 & 40 \\
\hline 2 & $\begin{array}{c}\text { Skor } \\
\text { Tertinggi }\end{array}$ & 94,83 & 87,93 \\
\hline 3. & $\begin{array}{c}\text { Skor } \\
\text { Terendah }\end{array}$ & 62,07 & 56,03 \\
\hline 4. & Rata-rata & 77,46 & 74,16 \\
\hline 5 & $\begin{array}{c}\text { Std. } \\
\text { Deviasi }\end{array}$ & 7,90059 & 7,86436 \\
\hline
\end{tabular}

Tabel 2. Rata-Rata Nilai Tiap Indikator Minat Belajar Siswa

\begin{tabular}{cccc}
\hline \multirow{2}{*}{ No } & $\begin{array}{c}\text { Indikator } \\
\text { Minat } \\
\text { Belajar }\end{array}$ & \multicolumn{2}{c}{ Rata-rata Nilai } \\
\cline { 3 - 4 } & Kelas & $\begin{array}{c}\text { Kelas } \\
\text { Eksperimen } \\
\text { Kontrol }\end{array}$ \\
\hline 1. & $\begin{array}{c}\text { Rasa } \\
\text { Senang }\end{array}$ & 75,94 & 76,04
\end{tabular}




\begin{tabular}{|c|c|c|c|}
\hline \multirow{3}{*}{ No } & \multirow{3}{*}{$\begin{array}{c}\text { Indikator } \\
\text { Minat } \\
\text { Belajar }\end{array}$} & \multicolumn{2}{|c|}{ Rata-rata Nilai } \\
\hline & & Kelas & Kelas \\
\hline & & Eksperimen & Kontrol \\
\hline 2 & Perhatian & 81,80 & 77,89 \\
\hline 3. & Keterlibatan & 77,81 & 74,14 \\
\hline 4. & $\begin{array}{c}\text { Ketertarikan } \\
\text { Siswa }\end{array}$ & 73,39 & 68,30 \\
\hline
\end{tabular}

Hasil analisis Independent Sample ttest diperoleh nilai signfikansi (2-tailed) sebesar 0,065. Penelitian ini menggunakan pengujian hipotesis pihak kanan (1-tailed), Nilai signifikansi (2-tailed) dibagi 2 dan diperoleh nilai signifikanasi (1-tailed) sebesar 0,0325. Hasil uji t menunjukkan bahwa nilai signifikansi tersebut lebih kecil dari taraf nyata $(0,05)$. Berdasarkan pedoman pengambilan keputusan, maka Ho: (nilai rata - rata minat belajar siswa kelas eksperimen tidak berbeda dengan kelas kontrol) ditolak yang berarti bahwa skor rata-rata minat belajar kelas eksperimen lebih baik dari kelas kontrol.

Minat belajar pada aspek perasaan senang antara kelas eksperimen dan kelas kontrol menunjukkan hasil yang berbeda. Pada analisis data, terlihat rata-rata nilai indikator perasaan senang pada kelas kontrol lebih besar dari pada kelas eksperimen. Kelas eksperimen terdapat siswa yang masih butuh penyesuaian diri terhadap pembelajaran berbasis proyek. Hal tersebut sesuai dengan pendapat Sani (dalam Nurfitriyanti, 2016), bahwa salah satu kelemahan model project based learning adalah tidak sesuai untuk siswa yang mudah menyerah dan tidak memiliki pengetahuan serta keterampilan yang dibutuhkan.

Penggunaan model pembelajaran berbasis proyek (Project Based Learning) membuat anak cenderung membuat siswa akan lebih konsentrasi dan perhatian pada saat mengikuti pembelajaran. Hal ini dapat dilihat dari rata-rata nilai tiap indikator minat belajar pada aspek perhatian pada kelas eksperimen lebih besar dari pada kelas kontrol. model pembelajaran berbasis proyek (Project Based Learning) membuat siswa lebih memperhatikan apa yang disampaikan oleh guru dan lebih berkonsetrasi saat pembelajaran. Perhatian siswa yang tinggi disebabkan oleh peran siswa dalam pembelajaran sangat penting.

Pembelajaran berbasis proyek merupakan investigasi mendalam tentang sebuah topik dunia nyata, hal ini akan berharga bagi atensi dan usaha peserta didik (kementrian Pendidikan dan Kebudayaan, 2013:228). Penggunaan model pembelajaran berbasis proyek (Project Based Learning) membuat anak cenderung membuat siswa akan lebih terlibat di dalam pembelajaran. Siswa lebih konsentrasi dan perhatian pada saat mengikuti pembelajaran. Hal ini dapat dilihat dari rata-rata nilai tiap indikator minat belajar pada aspek Keterlibatan pada kelas eksperimen lebih besar dari pada kelas kontrol. Perhatian dan keterlibatan siswa dalam pembelajaran fisika menjadi lebih besar ketika siswa mempunyai kemandirian dalam melaksanakan proyek untuk menjawab permasalahan atau pertanyaan esensial sesuai topik yang dipilih dengan mengaplikasikan hasil belajar lewat tindakan dan melakukan interaksi sosial kegiatan eksperimen dan observasi (learning by doing). Hal ini sesuai dengan pendapat Suryadi (2007:166), bahwa bentuk-bentuk aktivitas keterlibatan siswa dapat dilihat dari interaksi siswa-siswa, interaksi siswa-guru, kegiatan memanipulasi benda-benda nyata, dan menggunakan bahan ajar.

Indikator minat belajar pada aspek ketertarikan siswa, pada kelas eksperimen lebih tinggi dari pada kelas kontrol. Penelitian Rusnayati et al.(2016), bahwa siswa merespon senang terhadap pembelajaran berbasis proyek (project based learning) dan mendukung penerapannya di dalam pembelajaran. Angket minat belajar pada kelas eksperimen menunjukan bahwa siswa memiliki waktu khusus untuk belajar fisika di rumah. siswa tertatik mengisi jam kosong untuk belajar fisika bersama, tertarik untuk belajar mandiri maupun kelompok di dalam maupun di luar sekolah. Hal ini sesuai dengan penelitian. 
Rahmini et al.(2015) bahwa ada perubahan pada diri siswa setelah diajar pembelajaran berbasis proyek, antara lain yaitu siswa lebih tertarik dan lebih senang belajar fisika. Hutapea dan simanjutak (2017), didalam penelitiannya menyatakan bahwa pembelajaran dengan model project-based learning berpengaruh sangat baik terhadap hasil belajar siswa pada aspek keterampilan. Penggunaan pembelajaran berbasis proyek (Project Based Learning) didalam penelitian ini berpengaruh baik pada keterapilan proses sains siswa. Hal ini dapat dilihat pada Data nilai keterampilan proses sains siswa pada diperoleh dari hasil post-test siswa.

Hasil analisis uji Mann-Whitney diperoleh nilai signfikansi (2-tailed) sebesar 0,000. Penelitian ini menggunakan pengujian hipotesis pihak kanan (1-tailed), sehingga nilai signifikansi (2tailed) dibagi 2 dan diperoleh nili signifikanasi (1-tailed) sebesar 0,000. Nilai signifikansi tersebut lebih kecil dari taraf nyata $(0,05)$. Berdasarkan pedoman pengambilan keputusan, maka Ho: (nilai rata - rata keterampilan proses sains siswa kelas eksperimen tidak berbeda dengan kelas kontrol) ditolak yang berarti nilai rata-rata keterampilan proses sains kelas eksperimen lebih baik dari kelas kontrol. Nilai keterampilan proses sains siswa secara ringkas dapat dilihat pada Tabel 3.

Tabel 3. Rekapitulasi Nilai Keterampilan Proses Sains Siswa

\begin{tabular}{cccc}
\hline No & & $\begin{array}{c}\text { Kelas } \\
\text { Eksperimen }\end{array}$ & $\begin{array}{c}\text { Kelas } \\
\text { Kontrol }\end{array}$ \\
\hline 1. & $\begin{array}{c}\text { Jumlah } \\
\text { Siswa }\end{array}$ & 40 & 40 \\
\hline 2 & $\begin{array}{c}\text { Skor } \\
\text { Tertinggi }\end{array}$ & 87,50 & 79.17 \\
\hline 3. & $\begin{array}{c}\text { Skor } \\
\text { Terendah }\end{array}$ & 54,17 & 37.50 \\
\hline 4. & Rata-rata & 73.54 & 61.56 \\
\hline 5 & $\begin{array}{c}\text { Std. } \\
\text { Deviasi }\end{array}$ & 8.36285 & 8.30627 \\
\hline
\end{tabular}

Hasil analisis data penelitian dapat disimpulkan bahwa model pembelajaran berbasis proyek (Project Based Learning) berpengaruh signifikan terhadap keterampilan proses sains siswa. Keterampilan proses sains siswa pada aspek melaksanakan eksperimen, merancang penelitian dan menganalisis penelitian, menggambarkan hubungan antar variabel di kelas eksperimen menunjukkan hasil yang lebih baik dari pada di kelas kontrol. Siswanto et al. (2016), bahwa untuk meningkatkan KPS seperti keterampilan mengamati, mengajukan hipotesis merencanakan percobaan, menginterpretasikan suatu data, menginterpretasikan grafik, meramal, menerapkan konsep, dan berkomunikasi, maka dapat dilakukan suatu inovasi pembelajaran melalui model pembelajaran berbasis proyek.

Keterampilan proses sains pada aspek membuat tabel dan membuat grafik pada kelas eksperimen menunjukan hasil yang lebih rendah dari pada di kelas kontrol. Siswa yang belum terbiasa dengan kegiatan percobaan atau kerja proyek akan mengalami kesulitan. Kesulitan dirasakan oleh peserta didik karena peserta didik terbiasa hanya menerima informasi atau materi pelajaran secara langsung dari guru. Pada kerja kelompok dikhawatirkan terdapat beberapa peserta didik yang kurang begitu aktif dan hanya mengandalkan bantuan dari teman. Hal inilah yang menjadi kendala guru dalam meningkatkan keterampilan setiap peserta didik. Fikriyah et al. (2015) didalam penelitiannya menjelaskan bahwa, salah satu kelemahan dari model pembelajaran berbasis proyek (project based learning) adalah beberapa siswa mengalami kesulitan selama proses pembelajaran akibat memiliki kelemahan dalam memahami percobaan dan mengumpulkan informasi.

Keberhasilan implementasi model pembelajaran berbasis proyek (Project Based Learning) di dalam kelas eksperimen ini tidak terlepas dari kendalakendala yang dihadapi. Kendala yang dihadapi meliputi, ruang laboratorium yang cukup jauh dari ruang kelas siswa, 
penataan ruang laboratorium yang belum rapi, banyaknya aktivitas non akademik yang terkadang mengganggu pembelajaran dan siswa jarang melakukan pembelajaran yang diterapkan sebelumnya sehingga masih membutuhkan waktu dalam membimbing siswa. Faktor yang ada dalam pembelajaran ini dapat dikelola dan dipersiapkan secara baik maka tujuan pembelajaran dapat tercapai secara maksimal. Pembahasan di atas menunjukkan bahwa pembelajaran fisika dengan mengunakan model pembelajaran berbasis proyek (Project Based Learning) dapat digunakan sebagai informasi dan alternatif untuk mengajar fisika, memperbaiki minat belajar siswa dan meningkatkan keterampilan proses sains siswa.

\section{SIMPULAN DAN SARAN}

Berdasarkan hasil dan pembahasan pada penelitian ini, maka dapat disimpulkan antara lain: (1) model pembelajaran berbasis proyek (Project Based Learning) berpengaruh signifikan terhadap minat belajar siswa pada pembelajaran fisika di SMAN Balung; dan (2) model pembelajaran berbasis proyek (Project Based Learning) berpengaruh signifikan terhadap keterampilan proses sains siswa pada pembelajaran fisika di SMAN Balung.

Sebagai tindak lanjut dari hasil penelitian ini maka beberapa saran yang dapat diberikan antara lain: (1) bagi guru, dalam menerapkan model pembelajaran berbasis proyek (Project Based Learning) diperlukan persiapan yang matang untuk merencanakan proses pembelajaran sehingga siswa tidak mudah bosan, siswa lebih termotivasi untuk mengikuti pelajaran dan waktu yang digunakan lebih efisien. Sebelum melaksanakan model pembelajaran berbasis proyek (Project Based Learning), sebaiknya di kenalkan terlebih dahulu cara membuat tabel, membuat grafik, serta mengumpulkan dan mengolah data; dan (2) bagi peneliti lain, diharapkan model berbasis proyek (Project Based Learning) dapat dijadikan alternatif untuk penelitian selanjutnya dalam pengembangan pembelajaran.

\section{DAFTAR PUSTAKA}

Budianti, Y. dan I. Safiyyah. 2017. Upaya Meningkatkan Keterampilan Proses melalui Model Siklus Belajar (Learning Cycle) pada Pembelajaran Ilmu Pengetahuan Alam Siswa Kelas IV SD Negeri Wanasari 14 Bekasi. Jurnal Pendidikan Sekolah Dasar. 5 (01): 72-82.

Fikriyah, M., Indrawati, dan A. A. Gani. 2015. Model Pembelajaran Berbasis Proyek (Project Based Learning) disertai Media Audio-Visual dalam Pembelajaran Fisika di SMAN 4 Jember. Jurnal Pembelajaran Fisika. 4(02): 181-186.

Hardianti, D., M. Ali, dan Syamsu. 2016. Perbedaan Hasil Belajar Fisika Siswa untuk Model Pembelajaran Berbasis Proyek dengan Model Pembelajaran Langsung pada Kelas $X$ SMA Negeri 7 Palu. Jurnal Pendidikan Fisika Tadulako (JPFT). 4(2): 6-9.

Hila, L. Q., S. R. Eny, dan M. Sujiyo. 2015. Analisis Isi Buku Sekolah Elektronik (BSE) Biologi Kelas XI Semester 1 Berdasarkan Literasi Sains. EDUSAINS. 7(1): 1-10.

Hutapea, J. dan M. P. Simanjutak. 2017. Pengaruh Model Pembelajaran Project Based Learning (Pjbl) terhadap Hasil Belajar Siswa SMA. Jurnal Inovasi Pembelajaran Fisika (INPAFI). 5(1): 48-55.

Kementerian Pendidikan dan Kebudayaan. 2013. Materi Pelatihan Guru Implementasi Kurikulum 2013. 
Jakarta: Badan Pengembangan Sumber daya Manusia Pendidikan dan Kebudayaan dan Penjaminan Mutu Pendidikan.

Kholifudin, M.Y. 2013. Pembelajaran Fisika Berbasis Proyek Pembuatan Alat Resonansi Bunyi dari Lampu Neon Bekas untuk Membentuk Kerja Ilmiah dan Sikap Ilmiah pada Siswa. Prosiding Pertemuan Ilmiah XXVII HFI Jateng \& DIY. 23 Maret 2013. HFI DIY-Jateng: 79-82.

Leung, Y. 2015. A School-Based Study on Situational Interest of Investigative Study in Senior Physics. AsiaPacific Forum on Science Learning and Teaching. 16(2): 1-23.

Markawi, N. 2013. Pengaruh Keterampilan Proses Sains, Penalaran, dan Pemecahan Masalah terhadap Hasil Belajar Fisika. Jurnal Formatif. 3(01): 11-25.

Na'imah, N. J., Supartono, dan S. Wardani. 2015. Penerapan Pembelajaran berbasis Proyek Berbantuan E-Learning untuk Meningkatkan Hasil Belajar Siswa. Jurnal Inovasi Pendidikan Kimia. 9(02): 1556-1574.

Neizhela A., dan Mosik. 2015. Meningkatan Hasil Belajar Melalui Pendekatan Kontekstual dengan Metode Think Pair Share Materi Kalor pada Siswa SMP. Unnes Physics Education Journal. 4(1): 3642.

Nurfitriyanti, M. 2016. Model Pembelajaran Project Based Learning terhadap Kemampuan Pemecahan Masalah Matematika. Jurnal Formatif. 6(02): 149-160.

Nurmaliati. 2017. Perbedaan Hasil Belajar Fisika Menggunakan Model
Pembelajaran Kooperatif Tipe The Power Of Two dengan Tipe Think Pairs Check pada Siswa Kelas Xi Sekolah Menengah Atas. Jurnal Pendidikan Unsika. 5(01): 42-46.

Rahmini, Muris, dan B. D. Amin. 2015. Pengaruh Pembelajaran Berbasis Proyek terhadap Motivasi Belajar. Jurnal Sains dan Pendidikan Fisika. 11(02): 161-168.

Rusnayati, H., G. F. Gumelar, dan D. Rusdiana. 2016. Penerapan Model Pembelajaran Berbasis Proyek untuk Meningkatkan Hasil Belajar Siswa Sekolah Menengah Pertama (SMP) Berdasarkan Gaya Belajar Vark (Visual). Prosiding Seminar Nasional Fisika (E-Journal) SNF. Departemen Pendidikan Fisika. 5 (3). 28 Mei 2016. Program Studi Pendidikan Fisika Fakultas MIPA Universitas Negeri Jakarta: 27-32.

Sastrika, I.A.K., I.W. Sadia, dan Muderawan, I.W. 2013. Pengaruh Model Pembelajaran Berbasis Proyek Terhadap Pemahaman Konsep Kimia dan Keterampilan Berpikir Kritis. e-Journal Progam Pascasarjana Universitas Pendidikan Ganesha. 3(01): 1-10.

Sembiring, R. B. dan Mukhtar. 2013. Strategi Pembelajaran dan Minat Belajar terhadap Hasil Belajar Matematika. Journal Teknologi Pendidikan. 6(02): 214-229

Setiyatmoko, C. 2015. Implementasi Model Pembelajaran Berbasis Proyek Sebagai Upaya untuk Meningkatkan Prestasi Belajar dan Kinerja Ilmiah Siswa. Jurnal Ilmiah Pendidikan (JIP) PGRI Klungkung. 1(1): 93-107. 
Siswanto, Yusiran, M.F. Fajarudin. 2016. Keterampilan Proses Sains dan Kemandirian Belajar Siswa: Profil dan Setting Pembelajaran untuk Melatihkannya. Gravity: Jurnal Ilmiah Penelitian dan Pembelajaran Fisika. 2(02):190-202.

Hartono, D. P. 2016. Relationship Between Learning Motivation and Learning Method Against Learning Achievement Student Semester Subjects Meteorology and Climatology at the University of PGRI Palembang 2015. Jurnal Media Komunikasi Geografi. 17(01): 18-27.
Suryadi. 2007. Ilmu dan Aplikasi Pendidikan Bagian 3. Bandung: PT.IMTIMA.

Wati, R., I. D. P. Nyeneng, dan E. Suyanto. 2017. Pengaruh Minat Belajar terhadap Hasil Belajar Fisika pada Model Pembelajaran Inkuiri Terbimbing. Jurnal Pembelajaran Fisika. 5(02): 21-32. 